Review

\title{
The Utility of Image-Based Point Clouds for Forest Inventory: A Comparison with Airborne Laser Scanning
}

\author{
Joanne C. White ${ }^{1 \%}$, Michael A. Wulder ${ }^{1}$, Mikko Vastaranta ${ }^{2}$, Nicholas C. Coops ${ }^{3}$, Doug Pitt ${ }^{4}$ \\ and Murray Woods 5
}

1 Canadian Forest Service (Pacific Forestry Centre), Natural Resources Canada, 506 West Burnside Road, Victoria, British Columbia V8Z 1M5, Canada; E-Mail: mike.wulder@nrcan.gc.ca

2 Department of Forest Sciences, University of Helsinki, FI-00014 Helsinki, Finland;

E-Mail: mikko.vastaranta@helsinki.fi

3 Integrated Remote Sensing Studio, Department of Forest Resources Management, Faculty of Forestry, University of British Columbia, 2424 Main Mall, Vancouver, British Columbia V6T 1Z4, Canada; E-Mail: nicholas.coops@ubc.ca

4 Canadian Wood Fibre Centre, Canadian Forest Service, Natural Resources Canada, Sault Ste. Marie, Ontario, P6A 2E5, Canada; E-Mail: doug.pitt@nrcan.gc.ca

5 Southern Science \& Information Section, Ontario Ministry of Natural Resources, North Bay, Ontario P1A 4L7, Canada; E-Mail: murray.woods@ontario.ca

* Author to whom correspondence should be addressed; E-Mail: joanne.white@nrcan.gc.ca; Tel.: +1-250-298-2402; Fax: +1-250-363-0775.

Received: 17 May 2013; in revised form: 17 June 2013 / Accepted: 19 June 2013 /

Published: 26 June 2013

\begin{abstract}
Airborne Laser Scanning (ALS), also known as Light Detection and Ranging (LiDAR) enables an accurate three-dimensional characterization of vertical forest structure. ALS has proven to be an information-rich asset for forest managers, enabling the generation of highly detailed bare earth digital elevation models (DEMs) as well as estimation of a range of forest inventory attributes (including height, basal area, and volume). Recently, there has been increasing interest in the advanced processing of high spatial resolution digital airborne imagery to generate image-based point clouds, from which vertical information with similarities to ALS can be produced. Digital airborne imagery is typically less costly to acquire than ALS, is well understood by inventory practitioners, and in addition to enabling the derivation of height information, allows for visual interpretation of attributes that are currently problematic to estimate from ALS (such as species, health status, and maturity). At present, there are two limiting factors associated
\end{abstract}


with the use of image-based point clouds. First, a DEM is required to normalize the image-based point cloud heights to aboveground heights; however DEMs with sufficient spatial resolution and vertical accuracy, particularly in forested areas, are usually only available from ALS data. The use of image-based point clouds may therefore be limited to those forest areas that already have an ALS-derived DEM. Second, image-based point clouds primarily characterize the outer envelope of the forest canopy, whereas ALS pulses penetrate the canopy and provide information on sub-canopy forest structure. The impact of these limiting factors on the estimation of forest inventory attributes has not been extensively researched and is not yet well understood. In this paper, we review the key similarities and differences between ALS data and image-based point clouds, summarize the results of current research related to the comparative use of these data for forest inventory attribute estimation, and highlight some outstanding research questions that should be addressed before any definitive recommendation can be made regarding the use of image-based point clouds for this application.

Keywords: airborne laser scanning (ALS); LiDAR; forest inventory; area-based approach; point cloud; digital photogrammetry; semi-global matching (SGM); digital surface model (DSM)

\section{Introduction}

The capacity to acquire information characterizing the three-dimensional structure of forest canopies has revolutionized forest inventories around the globe [1]. Airborne Laser Scanning (ALS), also referred to as Light Detection and Ranging (LiDAR), has been the primary data source for three-dimensional information on forest vertical structure [2-6], however, there is an increasing interest in the use of high spatial resolution digital aerial imagery to generate information analogous to ALS data [7-9] to support forest inventory and monitoring. This interest in alternative technologies for acquiring accurate height information can be attributed to needs to control costs, but also to provide data that is complementary to traditional inventory practices, available technical capacity, and current regulatory requirements. Further, for those that are interested in utilizing ALS data for forest inventory, certain attributes remain difficult to obtain without imagery, such as species composition, maturity, and health status [5].

The integration of ALS into operational forest inventories was pioneered in Scandinavian countries such as Norway, Finland, and Sweden [10], and several European countries now have (e.g., Denmark, the Netherlands, and Switzerland), or are in the process of acquiring (e.g., Finland and Sweden), national ALS coverages [8]. National circumstances, including management, productivity, access, and stewardship responsibilities, influence the need for national coverage of ALS data. In 2011, it was estimated that about $30 \%$ of the conterminous United States had ALS coverage of some form [11]. ALS coverage in Canada varies by jurisdiction, with certain areas demonstrating a commitment to ALS acquisition, processing, and incorporation to natural resource management and reporting activities [12]. 
Approaches for deriving forest inventory information from ALS data are either based on individual tree detection and characterization [13], or on area-based statistical summaries of ALS point clouds [14]. The area-based approach to developing forest inventories from ALS data has been widely implemented in many areas across a broad range of forest types (Table 1). The successful application of the area-based approach is predicated on accurate measurements of forest height and height variation from ALS data. The goal of the area-based approach is to generate wall-to-wall estimates and maps of inventory attributes such as basal area or volume [14].

Table 1. Examples of studies that have applied the area-based approach to Airborne Laser Scanning (ALS) data.

\begin{tabular}{|c|c|c|}
\hline Study & Location & Forest Type \\
\hline $\begin{array}{l}\text { Næsset and } \\
\text { Bjerknes, } 2001 \text { [15] }\end{array}$ & Southeast Norway & $\begin{array}{l}\text { Young forests (i.e., }<6 \mathrm{~m} \text { in height) dominated by Norway } \\
\text { spruce (Picea abies (L.) Karst.) and Scots pine } \\
\text { (Pinus sylvestris L.). }\end{array}$ \\
\hline Lim et al., 2003 [16] & Ontario, Canada & $\begin{array}{l}\text { Mature sugar maple (Acer saccharum Marsh.) } \\
\text { and yellow birch (Betula alleghaniensis Britton). }\end{array}$ \\
\hline $\begin{array}{l}\text { Holmgren, } \\
2004[17]\end{array}$ & Southwest Sweden & $\begin{array}{l}\text { Norway spruce (Picea abies (L.) Karst.), Scots pine } \\
\text { (Pinus sylvestris L.) and birch (Betula spp.). }\end{array}$ \\
\hline $\begin{array}{l}\text { Corona and } \\
\text { Fattorini, } 2008 \text { [18] }\end{array}$ & Northern Italy & $\begin{array}{l}\text { Lowland forest dominated by Pedunculate oak (Quercus robur } \\
\text { L.), European turkey oak (Quercus cerris L.), and European } \\
\text { hornbeam (Carpinus betulus L.). }\end{array}$ \\
\hline $\begin{array}{l}\text { Rooker Jensen et al., } \\
2006 \text { [19] }\end{array}$ & $\begin{array}{l}\text { Northern Idaho, } \\
\text { USA }\end{array}$ & $\begin{array}{l}\text { Douglas fir (Pseudotsuga menziesii (Mirb.) Franco), Ponderosa } \\
\text { pine (Pinus ponderosa Dougl. ex P. \& C. Laws.), Grand fir } \\
\text { (Abies grandis (Dougl. ex D. Don) Lindl.), Western Larch } \\
\text { (Larix occidentalis Nutt.), Lodgepole pine (Pinus contorta } \\
\text { Dougl. Ex Loud.), Engelmann spruce (Picea engelmanni } \\
\text { Parry ex Engelm.), Pacific yew (Taxus brevifolia Nutt.), and } \\
\text { mixed conifer. }\end{array}$ \\
\hline $\begin{array}{l}\text { Hawbaker et al., } \\
2010[20]\end{array}$ & $\begin{array}{l}\text { Southern } \\
\text { Wisconsin, USA }\end{array}$ & $\begin{array}{l}\text { Upland forests dominated by oak (Quercus spp.), ash (Fraxinus } \\
\text { spp.), and hickories (Carya spp.). Remnant white pine } \\
\text { (Pinus strobus), hemlock (Tsuga canadensis), and yellow birch } \\
\text { (Betula alleghaniensis) dominated stands are present on cooler } \\
\text { north facing slopes. }\end{array}$ \\
\hline $\begin{array}{l}\text { Woods et al., } \\
2011[21]\end{array}$ & Ontario, Canada & $\begin{array}{l}\text { Black spruce (Picea mariana [Mill.] BSP), white birch } \\
\text { (Betula papyrifera Marsh.), trembling aspen (Populous } \\
\text { tremuloides Michx.), jack pine (Pinus banksiana Lamb.), eastern } \\
\text { white cedar (Thuja occidentalis L.), white spruce (Picea glauca } \\
\text { [Moench] Voss), eastern larch (Larix laricina [Du Roi] K. } \\
\text { Koch), and balsam fir (Abies balsamea [L.] Mill.). }\end{array}$ \\
\hline $\begin{array}{l}\text { Lindberg and } \\
\text { Hollaus, } 2012 \text { [22] }\end{array}$ & Southwest Sweden & $\begin{array}{l}\text { Norway spruce (Picea abies), Scots pine (Pinus sylvestris), } \\
\text { birch (Betula pendula and Betula pubescens), oak } \\
\text { (Quercus robur). }\end{array}$ \\
\hline $\begin{array}{l}\text { Nord-Larsen and } \\
\text { Schumacher, } \\
2012[23]\end{array}$ & Denmark & $\begin{array}{l}\text { A wide range of forest ecotypes, stand treatments, } \\
\text { tree species, and tree species mixtures. }\end{array}$ \\
\hline
\end{tabular}


The area-based approach is accomplished in two stages (Figure 1). In the first stage, ALS data is acquired for the entire area of interest, tree-level measures are acquired from sampled ground plots, and predictive models are developed (e.g., regression or non-parametric methods). For the purposes of model development, the ALS point cloud is clipped to correspond to the area of each ground plot. Metrics (descriptive statistics) are calculated from the clipped normalized ALS point cloud and include measures such as mean height, standard deviation of height, height percentiles, canopy cover, etc. [14]. Attributes of interest are measured by ground crews (i.e., height, diameter), or are modeled (i.e., volume, biomass) for each ground plot. In the second stage of the area-based approach, the same metrics that are calculated for the clipped ALS point cloud, as described above, are generated for the wall-to-wall ALS data. The predictive models developed in the first stage are then applied to the entire area of interest to generate the desired wall-to-wall estimates and maps of estimated forest inventory attributes. The sample unit is a grid cell, the size of which relates to the size of the ground-measured plot. Once the predictive equations are applied, each grid cell will have an estimate for the attribute of interest. These grid-cell estimates can then be summarized to the forest stand level using existing inventory polygons (Figure 1). These estimates often meet or exceed standards for operational accuracy $[1,24]$.

Figure 1. Schematic of the area-based approach to estimating inventory attributes.

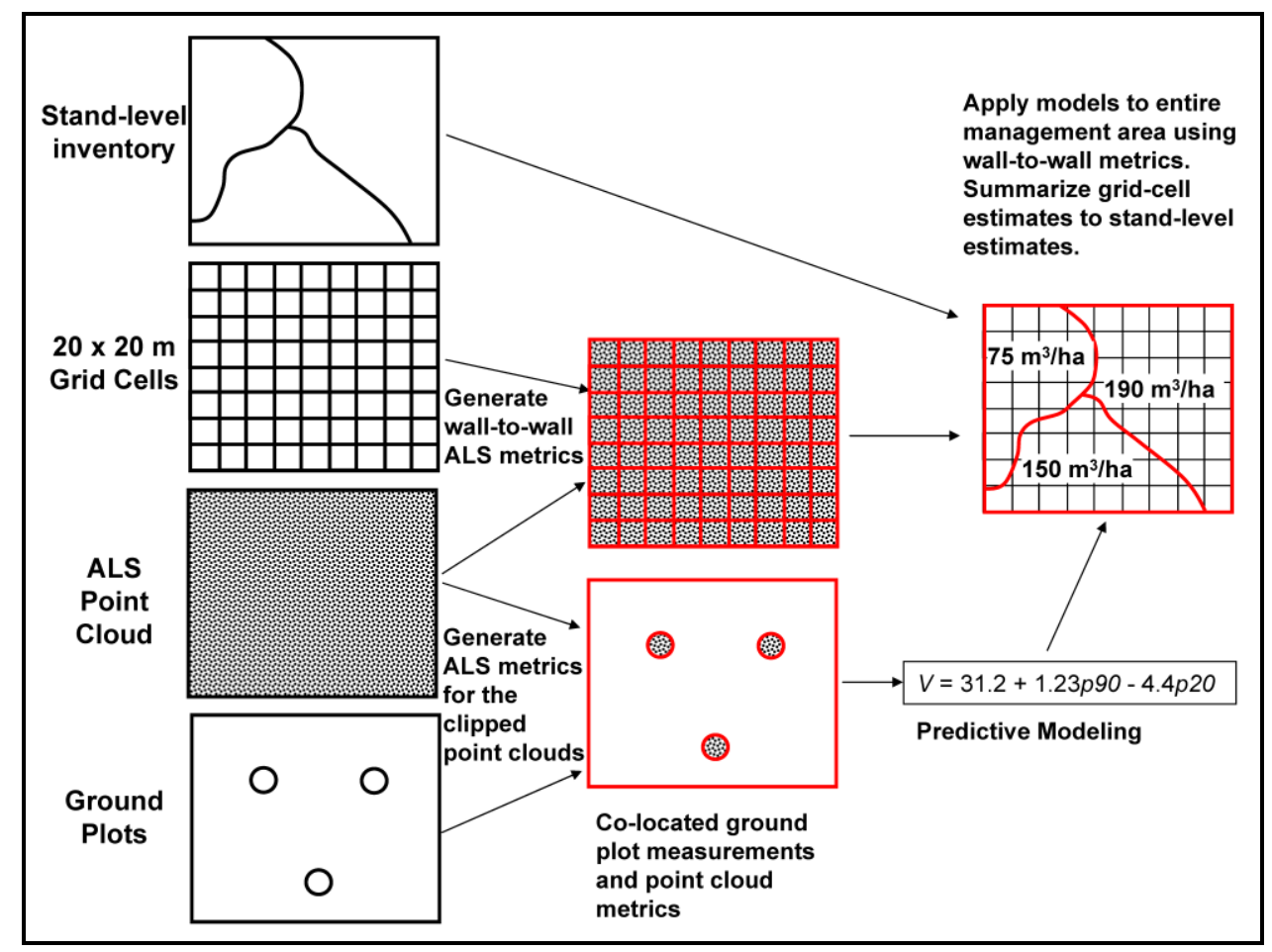

Several industrial forest management organizations and jurisdictional resource management agencies in Canada are acquiring ALS coverages over large areas. For example, the Government of Alberta has acquired more than 28 million ha of ALS data since 2008 (an area that is larger than the entire forested area of Sweden), and ALS is actively being used to support operational forest inventories in other regions of Canada (e.g., [21]). For the purposes of forest mapping and monitoring, it has been suggested that ALS data could be acquired at regular, but extended time periods (i.e., every 10 or 20 years, depending on forest and management considerations), with forest information updated 
periodically using image-based point clouds [9] derived from imagery acquired in between regular forest inventory cycles. In theory, the image-based point clouds could be used for area-based estimations in a fashion analogous to ALS data. At the time of writing, the operational implementation of this premise is hypothetical: the actual capacity for image-based point clouds and processing approaches to provide a replacement for ALS data for forest monitoring and inventory update is an active area of research.

The objective of this paper is to summarize key similarities and differences between ALS and image-based point clouds in terms of data acquisition, processing, and products generated, as well as the application of these data in the area-based approach for forest inventory attribute estimation. First, the basic features of ALS and image-based point clouds are described, followed by a comparison of considerations related to data collection, processing, and products. We then present results from the literature for two studies that have used ALS and image-based point clouds in the area-based approach to estimate forest inventory attributes. As this is a relatively nascent area of research, we highlight several issues that require further investigation prior to any definitive recommendation regarding the use of image-based point clouds as an information source for forest inventory.

\section{Airborne Laser Scanning (ALS) Data}

ALS systems have the capacity to directly measure the vertical distribution of vegetation and the underlying topography, resulting in the accurate estimation of both vegetation height and ground elevation. From these measures, three-dimensional digital surface models (DSMs) and bare earth digital elevation models (DEMs; also referred to as a digital terrain models or DTMs) can be generated. While there are many different types of LiDAR systems, discrete-return ALS systems are the most common type used in forestry applications [5]. A typical ALS system includes a laser ranging unit; an opto-mechanical scanner; control, monitoring, and recording units; a kinematic Global Positioning System (GPS); and an Inertial Measurement Unit (IMU) [25]. Discrete-return ALS systems operated in a scanning mode provide a three-dimensional point cloud over a swath width defined by both the sensor type and specifications, as well as the aircraft altitude. ALS systems provide a range measurement (distance) between the aircraft and the intercepted surfaces. The ALS systems typically used for forestry applications emit 50,000 to 150,000 laser pulses per second and are able to record up to five returns for each pulse emitted, with the first return typically coming from the top of the canopy [26]. The range measurements (z), along with the $x$ and $y$ locations for all intercepted features, form a three-dimensional point cloud. ALS instruments are characterized by a small-footprint $(<1 \mathrm{~m})$ and the number of returns recorded (1 to 5 returns per laser pulse), and are designed to acquire ground surface heights with sub-meter accuracy [27]. ALS surveys are typically designed with a 50\% overlap between swaths in order to ensure a dense and relatively uniform distribution of pulses [28]. A minimum pulse density of $0.5-1$ pulse per square meter is generally considered sufficient for the area-based approach [29-31], with greater pulse densities required in areas with steep terrain and dense forest canopies [32,33]. The classification of the ALS point cloud into ground and non-ground (i.e., vegetation) returns is typically undertaken by data providers using proprietary software or tools such as TerraScan (Terrasolid) or LP360 (QCoherent), and involves iterative algorithms and some manual intervention [34]. A DEM can be generated from the points identified as ground returns 
(i.e., lowest ground returns), and a DSM can be generated from those points identified as non-ground returns (i.e., highest vegetation returns). A DSM characterizes the upper level of the forest canopy and measures the heights of objects in meters above sea level.

The use of ALS in forest inventory and management is a relatively mature area of research and several literature reviews provide additional background information [2-6]. A canopy height model (CHM) can be generated by subtracting the DEM from the DSM, resulting in normalized aboveground object heights (i.e., tree heights). Similarly, the DEM may be used to normalize point cloud heights to aboveground heights. Some software programs, such as FUSION [35], use both the point cloud and the DEM to calculate ALS metrics, thereby normalizing the point cloud to aboveground heights dynamically during metric processing.

\section{Image-Based Point Clouds}

When an object is imaged from two different perspectives, stereophotogrammetry enables the measurement of its three-dimensional position relative to a reference datum (e.g., sea level). The process is analogous to our own visual perception of depth with normal binocular vision. Like our vision, stereophotogrammetry is based upon the principle of parallax, which refers to the apparent change in the relative position of stationary objects resulting from a change in viewing position [36]. In simple terms, stereophotogrammetry involves identifying a common point on each image. A line of sight (also referred to as a ray) is constructed from the camera viewpoint to the common point on each image. The intersection of the two rays is found using triangulation, and the three-dimensional position of the point is determined (i.e., $x, y, z$ ). Repetition of this process for the many points that make up the object or surface being viewed results in the image-based point cloud that can be used to generate a DSM. Manual methods of stereophotogrammetry have been used in forestry since the 1940s [37]; however, the evolution of computing technology and digital imagery have facilitated automation of the sterophotogrammetric measurement process and such methods began to emerge in Canada in the early 1990s [38]. Digital image systems (referred to as softcopy) have greatly streamlined forest inventory procedures [39].

Two noteworthy innovations in digital photogrammetry have resulted in the capacity to generate image-based point clouds that are similar in several respects to ALS point clouds. First, digital aerial cameras facilitate the easy acquisition of multiple overlapping images, without the previous level of effort and expense required to capture, develop, and scan analog photos. From overlapping images, an object can be visible on multiple image pairs, allowing for multi-view matching (not just stereo-matching), which reduces the opportunity for occlusions (i.e., shadows or areas that are not visible on the image), and improves geometric accuracy [7,40]. Second, rapid advances in the development of computer technology have made complex algorithms for image matching practical. The result of these innovations has been the generation of image-based point clouds and DSMs that are much more detailed and more accurate than was previously possible with traditional manual stereophotogrammetric processing.

The creation of an image-based point cloud and DSM requires high-spatial resolution aerial images with multi-image overlap [7,41]. Spatial resolution is defined by the Ground Sample Distance (GSD), which depends on flying height and sensor characteristics. Flying heights between 550 and $4800 \mathrm{~m}$ above ground level have been used with $60 \%-90 \%$ along-track and $30 \%-60 \%$ across-track overlap for 
forestry applications, providing GSDs ranging from 0.05 to $0.48 \mathrm{~m}[8,9]$. For forestry applications, the need for highly redundant (i.e., many overlapping images), multi-image information is especially acute to overcome occlusions that are common in the canopy [41,42]. There are currently several airborne optical photogrammetric systems capable of acquiring the stereo imagery required for image-based point cloud generation, including the Zeiss Intergraph Digital mapping camera, the Leica ADS, the Microsoft UltraCam, and the Rapid three-dimensional Mapper developed by SAAB [8].

The aim of image matching is to find corresponding points (objects) in images based on their radiometric and geometric similarity. The main automated photogrammetric image matching methods can be divided into area- or feature-based methods [40]. Area-based methods typically use a window of image pixels to search for the best match between images. Feature-based methods rely on matching between basic mapping entities, such as points, lines, and polygons. Current image processing software often uses a combination of these two methods for image matching [8,9,41]. A variant of the area-based method to image matching is termed "Global Image Matching". Global Image Matching methods seek to match each pixel in the image (as opposed to a window of pixels), and although these methods may be considered state-of-the-art in terms of the quality and resolution of the point clouds and DSMs that they can produce, they are computationally intensive and slow to process [43]. Hence, a method referred to as Semi-Global Matching (SGM) has emerged, which is a hybrid between global image and area-based matching approaches. SGM constrains the possibilities for pixel-wise matching using a cost function, thereby making the matching process markedly more efficient [44].

Regardless of the image-matching method used, stereo-matching parameters, image resolution, and differences in sun-angle and viewing geometry have a significant impact on the quality of image-based point clouds and DSMs. While technological innovations can improve image matching capacity, issues of sun angle and viewing geometry will be a factor in any optical image product that is acquired and used for point cloud and DSM generation [45]. Several issues that confound image matching, including issues specific to forest environments, are summarized in Table 2.

Photogrammetric matching of digital aerial images using approaches such as SGM results in the production of a three-dimensional point cloud with similarities to an ALS point cloud. However, as indicated above, the aforementioned photogrammetric matching process produces three-dimensional points for the upper canopy surface only, in contrast to the ALS data points, which are distributed between the ground surface and the upper canopy [46]. Recall that the ALS instruments typically used for forestry applications are able to record up to five returns for each pulse emitted. Therefore, a DSM built from an image-based point cloud is similar to a DSM that is built from first ALS returns only (Figure 2). Similar to an ALS-derived DSM, a DEM can be subtracted from an image-based DSM to give an estimate of aboveground object heights; however, the DEM must have a sufficiently high spatial resolution and vertical accuracy to enable this normalization. Such high quality, detailed DEMs, particularly under dense forest canopies, are typically only available from ALS data [27]. Finally, metrics may be calculated from the image-based point cloud that resemble — but are not necessarily the same-as those generated from the ALS point cloud. 
Table 2. Factors affecting the quality of an image matching product (adapted from Baltsavias et al. [42]).

\begin{tabular}{|c|c|}
\hline Context & Issues \\
\hline General issues & $\begin{array}{l}\text { - little or no texture on the surface being imaged; } \\
\text { - distinct object discontinuities (e.g., discrete boundary between a forest stand } \\
\text { and a harvested area); } \\
\text { - object with no flat surface; } \\
\text { - repetitive objects; } \\
\text { - occlusions; } \\
\text { - moving objects, including shadows; } \\
\text { - multilayered and transparent objects; } \\
\text { - radiometric artifacts like specular reflections and others; }\end{array}$ \\
\hline Forestry-specific & $\begin{array}{l}\text { - general issues are exacerbated when imagery is acquired during leaf-off conditions; } \\
\text { - excessive image displacement in areas with steep terrain and tall trees } \\
\text { as off-nadir angles increase (i.e., as distance increases from image center); } \\
\text { - moving objects: tree sway in moderate breezes can move tree tops one meter or more } \\
\text { (which is particularly problematic if tree sway is in different directions between } \\
\text { flight lines as this can create false parallax); } \\
\text { - when using feature-based image matching, points/edges of objects differ in } \\
\text { the images due to different viewpoints (not an issue with area-based matching, SGM). }\end{array}$ \\
\hline Multi-temporal & $\begin{array}{l}\text { - different sensors/cameras; } \\
\text { - different image scales; } \\
\text { - different image qualities; } \\
\text { - different illumination and atmospheric conditions; } \\
\text { - different image orientation (viewpoints and rotation angles). } \\
\text { - flying almost on the same date; }\end{array}$ \\
\hline $\begin{array}{l}\text { Mitigation } \\
\text { strategies } \\
\text { to the above } \\
\text { known problems }\end{array}$ & $\begin{array}{l}\text { - good and similar illumination and atmospheric conditions; } \\
\text { - high sun elevation; } \\
\text { - acquiring images with leaves on (same phenological conditions); } \\
\text { - increasing image overlap (which can also increase costs); } \\
\text { - similar image-acquisition parameters, using modern capabilities for precise navigation }\end{array}$ \\
\hline
\end{tabular}

\section{Comparison of ALS and Image-Based Point Clouds}

\subsection{Acquisition, Processing, and Products}

To date, there are a limited number of studies that have investigated the similarities and differences in the information derived from ALS and image-based point clouds. Comparisons between photogrammetric and ALS systems have been undertaken [7,47]. Although these two studies are not specific to forest environments, they do highlight several points worthy of consideration; key similarities and differences between ALS and digital imagery for acquisition, processing, products, metrics, and estimated inventory attributes are summarized in Table 3. 
Figure 2. A comparison of ALS and image-based canopy height models (CHMs) for a $61 \mathrm{~m}$ transect in a relatively homogenous single-layer, even-aged forest environment from Järnstedt et al. [9]. The ALS data had a point density of 10.43 points $/ \mathrm{m}^{2}$. The imagery had a Ground Sample Distance (GSD) of $0.25 \mathrm{~m}$. Both the ALS and image-based CHMs have a spatial resolution of $0.5 \mathrm{~m}$. The profiles illustrate the differences in canopy representation between the two surfaces: the image-based CHM has no ground returns and does not characterize gaps in the canopy.
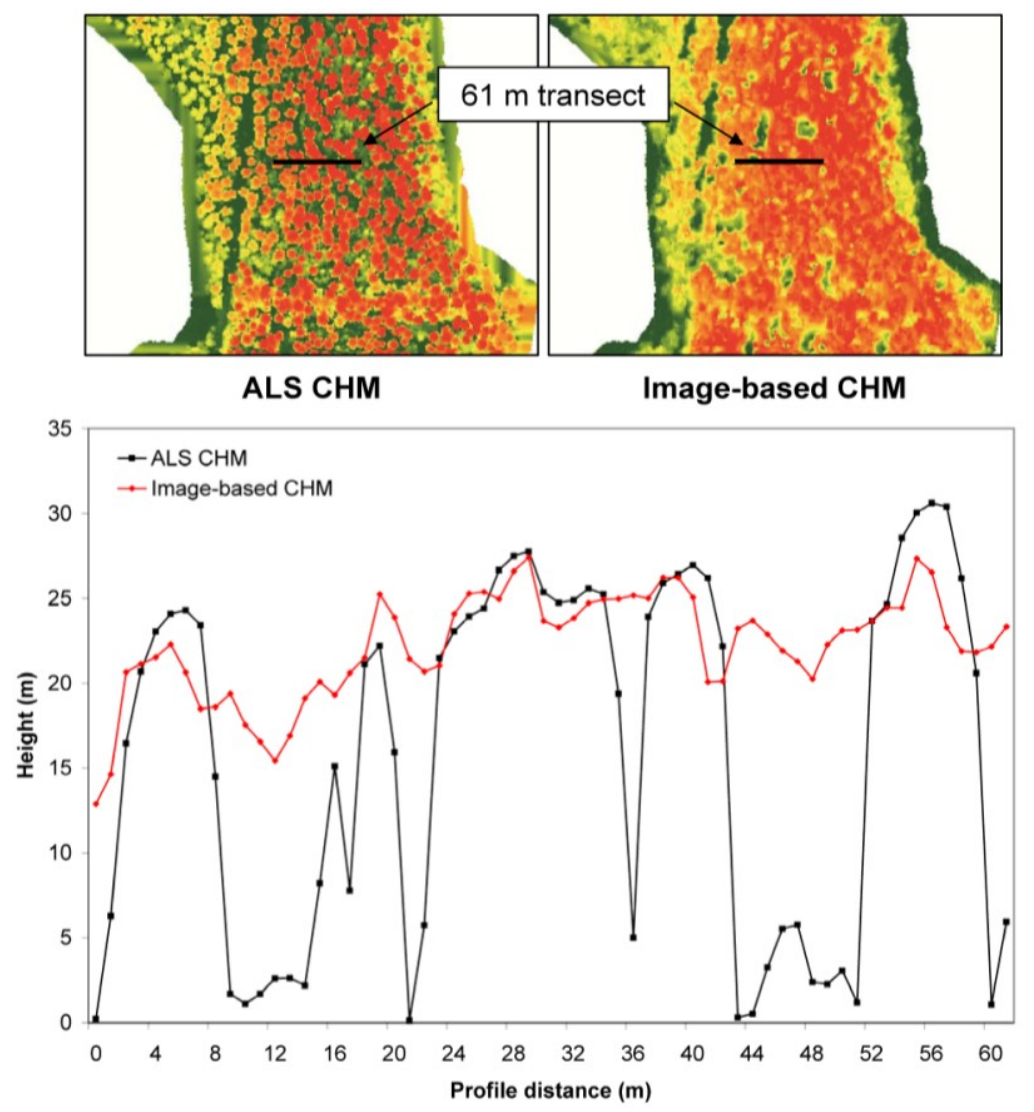

Table 3. A summary of key similarities and differences between ALS and image-based point clouds.

\begin{tabular}{|c|c|c|c|}
\hline Parameter & Advantage & Notes & Reference \\
\hline \multicolumn{4}{|c|}{ ACQUISITION } \\
\hline $\begin{array}{l}\text { Flight } \\
\text { planning }\end{array}$ & Imagery & $\begin{array}{l}\text { Digital imagery has wide swaths and overlap in both the } \\
\text { along-track and cross-track directions that makes the block } \\
\text { geometry more stable, providing redundancy for processing. } \\
\text { In steep terrain, planning for ALS is particularly challenging as } \\
\text { maximum flying height is restricted by laser power. The number } \\
\text { and positioning of GPS base stations must be considered. }\end{array}$ & $\begin{array}{l}\text { Baltsavias, } \\
1999 \text { [47] }\end{array}$ \\
\hline $\begin{array}{l}\text { Flying time } \\
\text { and area } \\
\text { covered }\end{array}$ & Imagery & $\begin{array}{l}\text { Image platforms are able to fly higher and faster than ALS } \\
\text { platforms. Imaging instruments will typically have a FOV of } 75^{\circ} \text {; } \\
\text { ALS FOV (for forest applications) are } \leq 25^{\circ} \text {. } \\
\text { Thus, for the same number of flying hours, image acquisition can } \\
\text { cover a much larger area. }\end{array}$ & $\begin{array}{l}\text { Baltsavias, } \\
1999 \text { [47] } \\
\text { Leberl et } \\
\text { al., } 2010 \text { [7] }\end{array}$ \\
\hline
\end{tabular}


Table 3. Cont.

\begin{tabular}{|c|c|c|c|}
\hline Parameter & Advantage & Notes & Reference \\
\hline \multicolumn{4}{|c|}{ ACQUISITION } \\
\hline $\begin{array}{l}\text { Flying } \\
\text { conditions }\end{array}$ & ALS & $\begin{array}{l}\text { More flying hours per day are possible with ALS, which is } \\
\text { insensitive to shadow. Imagery is strongly influenced by solar } \\
\text { illumination and view angles (sun, surface, and sensor geometry). } \\
\text { Occlusions caused by shadows are particular problematic for } \\
\text { generation of image-based point clouds in forest canopies. }\end{array}$ & $\begin{array}{l}\text { Baltsavias, } \\
1999[47] \\
\text { Gehrke } \\
\text { et al., } \\
2011[43]\end{array}$ \\
\hline \multicolumn{4}{|c|}{ PROCESSING } \\
\hline Efficiency & ALS & $\begin{array}{l}\text { Time required to go from acquisition to point cloud is shorter for } \\
\text { ALS, although this advantage has narrowed over time with the } \\
\text { advent of fully digital photogrammetric workflows. }\end{array}$ & $\begin{array}{l}\text { Baltsavias, } \\
1999[47] \\
\text { Leberl } \\
\text { et al., } \\
2010[7]\end{array}$ \\
\hline \multicolumn{4}{|c|}{ PRODUCTS } \\
\hline Outputs & $\begin{array}{l}\text { ALS } \\
\text { Imagery }\end{array}$ & $\begin{array}{l}\text { Imagery is limited to the production of a DSM. Imagery only } \\
\text { provides measures for the canopy surface as visible from the air. } \\
\text { ALS can penetrate the forest canopy and provides measurements } \\
\text { from the canopy through to the ground surface, enabling the } \\
\text { generation of DEMs, DSMs, and CHMs. } \\
\text { The advantage of imagery is that it enables stand delineation and } \\
\text { visual interpretation of species and other attributes that cannot (at } \\
\text { this time) be derived from the ALS. }\end{array}$ & $\begin{array}{l}\text { Baltsavias, } \\
1999 \text { [47] } \\
\text { Bohlin et } \\
\text { al., } 2012 \text { [8] } \\
\text { Järnstedt et } \\
\text { al., } 2012 \text { [9] }\end{array}$ \\
\hline \multicolumn{4}{|c|}{ PRODUCTS } \\
\hline Resolution & Imagery & $\begin{array}{l}\text { Much greater point densities are attainable with imagery than } \\
\text { with ALS for a given cost, owing to smaller GSDs and image } \\
\text { overlap that enables a large number of independent three- } \\
\text { dimensional pixel matches. The higher density of points may } \\
\text { enable a better representation of discontinuities. }\end{array}$ & $\begin{array}{l}\text { Leberl et } \\
\text { al., } 2010[7] \\
\text { Baltsavias, } \\
1999[47]\end{array}$ \\
\hline Accuracy & ALS & $\begin{array}{l}\text { Accuracies are comparable between ALS and imagery for well- } \\
\text { defined surfaces. More direct comparisons of canopy heights and } \\
\text { other inventory metrics derived from the two data sources are } \\
\text { required in a range of forest environments. } \\
\text { The higher density of points in image-based point clouds does not } \\
\text { necessarily result in greater vertical accuracies }\end{array}$ & $\begin{array}{l}\text { Haala et al., } \\
2010 \text { [47] } \\
\text { Leberl et } \\
\text { al., } 2010 \text { [7] }\end{array}$ \\
\hline
\end{tabular}

In terms of flight planning, the advantage clearly lies with imagery, particularly in steep and/or complex terrain, primarily due to the higher altitude at which imagery can be acquired relative to ALS. The higher altitude associated with image acquisition, combined with the larger field of view of imaging instruments, also results in greater spatial coverage for imagery relative to ALS (given the same number of flying hours). One key advantage of ALS over imagery however, is the flexibility associated with ALS acquisition. Imagery is strongly influenced by solar illumination and view angles, and occlusions or shadows in the forest canopy can greatly limit image matching capabilities [43]. As a result, the number of hours available for image acquisition on any given day is limited, particularly at high latitudes. This limitation is partially offset by the higher altitudes, faster flying speeds, and greater 
field-of-view associated with imaging platforms. In contrast, ALS is not influenced by the presence of shadows or daylight, and therefore affords more hours for acquisition. As an active sensing system, ALS data can theoretically be acquired at night, but in practice this is uncommon. In addition, although both image and ALS platforms are adversely affected by inclement weather (e.g., precipitation), as imaging platforms typically fly at higher altitudes, there is a greater opportunity for haze or cloud to negatively impact image acquisition.

In terms of processing, ALS data currently have an advantage over image-based approaches. The time required to acquire and process ALS data into a useable point cloud is generally less than for imagery, however as digital image workflows become increasingly efficient, this advantage will likely become less relevant over time. With regard to the outputs generated, ALS data clearly have an advantage, enabling the production of both a DSM and a DEM. In contrast, image-based approaches are limited to DSM generation when vegetation cover is present and the ground is obscured [43]. However, imagery that is acquired to build an image-based DSM enables visual interpretation of species and other attributes that are also required for forest inventory purposes. For new inventories (and for subsequent inventory cycles), imagery must be acquired to augment the information from ALS.

With regards to resolution, the image-based point cloud is capable of a greater point density than ALS data, for a given cost, as a function of the GSD and the number of independent three-dimensional pixel matches [7]. However, research into the impact that increasing ALS point density has on the accuracy of forest inventory attribute estimation would suggest that the increased point density afforded by image-based point clouds may not be of any particular advantage for the area-based approach (e.g., [30,31,48]). The higher point density associated with image-based point clouds may however be advantageous for characterizing discontinuities, such as the boundaries between features (e.g., between a forest stand and a harvested area) [7], but does not contribute to greater vertical accuracies. In addition, the higher density afforded by image-based point clouds may aid in the identification of individual tree crowns (independently or fused with imagery) that current operational ALS missions cannot support at their lower point densities.

A rigorous accuracy assessment of an ALS-derived DEM was conducted in a mountainous area under varying vegetation conditions (bare ground to dense canopy) [27]. The authors found that the average error in elevation was $0.22 \mathrm{~m}$, with errors increasing with increasing vegetation cover. Under a full canopy, the elevation error $(0.31 \mathrm{~m})$ was almost double the error for a recently harvested area $(0.16 \mathrm{~m})$. Hodgson and Bresnahan [49] likewise found that errors varied with vegetation conditions and type, and were not just a result of ALS system error, but were also a function of post-processing procedures and the terrain itself (elevation error on steep slopes $\left(>25^{\circ}\right)$ was twice the error found on low slopes (e.g., $\left.1.5^{\circ}\right)$ ). Using stereophotogrammetry, Korpela [37] measured individual tree heights, with standard deviations ranging from 0.3 to $1.0 \mathrm{~m}$. Errors associated with individual tree heights derived from ALS data are typically less than $1.0 \mathrm{~m}$ [50,51], and in some cases, less than $0.5 \mathrm{~m}$ [52], while errors associated with plot-level mean and maximum canopy heights are less than $0.5 \mathrm{~m}[14,53-56]$.

The accuracy of image-based point clouds is influenced by both the flying altitude and degree of image overlap and is considered to be comparable to the accuracy of ALS point clouds, although few studies have conducted or reported comparative evaluations. Haala et al. [42] compared the accuracies of an ALS and image-based point cloud for a well-defined surface (a level sports field) and found that 
the standard deviation for the ALS measures (with a point density 10 points $/ \mathrm{m}^{2}$ ) was less than $2 \mathrm{~cm}$, whilst the standard deviation for the image-based point cloud (with a point density of 20 points $/ \mathrm{m}^{2}$ ) was less than $5.5 \mathrm{~cm}$. To date, the authors are not aware of any rigorous assessments that compare the relative accuracies of canopy heights derived from ALS and image-based point clouds over a range of forest types and terrain complexities.

\subsection{Area-Based Approach for Estimating Forest Inventory Attributes}

To the authors' knowledge, there are currently only two studies in the peer-reviewed literature that compare the use of ALS and image-based point clouds/DSMs for forest attribute estimation. Bohlin et al. [8] estimated tree height, stem volume, and basal area using height, density, and texture metrics derived from an image-based DSM (with heights normalized using a ALS-derived DEM). The objective of their study was to determine the impact of flying altitude and image overlap on the area-based estimation of forest inventory attributes, as both these factors can affect the accuracy of the image-based DSM $[7,47]$. The study area was a managed forest estate with relatively flat terrain that was dominated by Norway spruce (Picea abies (L.) Karst), Scots Pine (Pinus sylvestris L.), and Birch species (Betula spp.). Discrete-return, small footprint $(25 \mathrm{~cm})$ ALS data were acquired with a pulse density of 7 pulses $/ \mathrm{m}^{2}$. Digital airborne imagery was acquired using a DMC system with GSDs of $0.12 \mathrm{~m}$ and $0.48 \mathrm{~m}$. Predictive models were developed using the area-based approach, with a grid cell size of $18 \mathrm{~m} \times 18 \mathrm{~m}$ corresponding to a ground plot size of $314 \mathrm{~m}^{2}$ (circular plot with a $10 \mathrm{~m}$ radius). Height metrics were generated from the ALS and image-based point clouds and included height percentiles corresponding to the 10,20,40,60, 80, 90 and 100 quantiles of the point heights. Canopy density metrics included proportions of points that were $20 \%, 30 \%, 40 \%$, and $50 \%$ of the maximum height. Given that ALS pulses penetrate the canopy and capture the full vertical height distribution, whereas the image-based DSM and point cloud only characterize the canopy surface, the authors postulated that canopy density metrics calculated from the image-based point cloud would not have the same explanatory power as canopy density metrics calculated from the ALS point cloud. The authors therefore generated height-based texture metrics to augment the typical suite of calculated metrics. The results of this study indicate that increasing image overlap and decreasing GSD from 0.48 to $0.12 \mathrm{~m}$ (by decreasing flying altitude) did not improve the accuracy of forest attribute estimates. Stand-level accuracies (RMSE \%) were assessed using ground measures $(n=24)$ for tree height $(8.8 \%)$, stem volume (13.1\%), and basal area (14.9\%). These RMSEs are slightly higher than those obtained by Holmgren using ALS-derived metrics and an area-based approach for the same study site. Holmgren [17] obtained stand-level accuracies (RMSE \%) of 3\%, 10\%, and 11\% for tree height, stem volume, and basal area respectively (Table 4). 
Table 4. Summary of relative RMSE $(\%)[8,9]$.

\begin{tabular}{lcccc}
\hline \multirow{2}{*}{$\begin{array}{l}\text { Forest Inventory } \\
\text { Attributes }\end{array}$} & \multicolumn{2}{c}{ Bohlin et al., 2012 [8] } & \multicolumn{2}{c}{ Järnstedt et al., 2012 [9] } \\
\cline { 2 - 5 } & Image & ALS & Image & ALS \\
\hline Mean Height & $8.8 \%$ & $3 \%$ & $28.2 \%$ & $18.6 \%$ \\
Dominant Height & $\mathrm{N} / \mathrm{A}$ & $\mathrm{N} / \mathrm{A}$ & $18.2 \%$ & $11.8 \%$ \\
Basal Area & $14.9 \%$ & $11 \%$ & $36.2 \%$ & $27.9 \%$ \\
Volume & $13.1 \%$ & $10 \%$ & $40.4 \%$ & $31.3 \%$ \\
Diameter & $\mathrm{N} / \mathrm{A}$ & $\mathrm{N} / \mathrm{A}$ & $33.7 \%$ & $25.3 \%$ \\
\hline
\end{tabular}

Järnstedt et al. [9] compared the accuracy of forest attribute estimates generated from ALS and from an image-based DSM (normalized using an ALS-derived DEM). The 2000 ha study area was dominated by even-aged, single-layer stands of Scots pine (Pinus sylvestris L.) and Norway spruce (Picea abies (L.) Karst). Elevation in the study area ranged from 125 to $185 \mathrm{~m}$ above sea level. Discrete-return, small footprint $(10 \mathrm{~cm})$ ALS data were acquired with a pulse density of $10.43 \mathrm{pulses} / \mathrm{m}^{2}$. Digital airborne imagery was acquired using a Microsoft UltracamXp imaging sensor with a GSD of $0.25 \mathrm{~m}$. Predictive models were developed using the area-based approach, with a ground plot size of $300 \mathrm{~m}^{2}$. Forest attributes of interest included diameter, mean height, dominant height, basal area, and growing stock volume. Metrics were generated from the ALS and image-based point clouds and included: minimum, maximum, mean, and mode of height; height at certain percentiles $(0 \%, 5 \%$, $10 \%, \ldots, 100 \%$ ); and proportion of ALS pulses or image-based DSM measures at certain percentiles of height (as an indication of density). The authors found that ALS-based models had greater accuracies for all the attributes considered (Table 4). It should be noted that the ALS pulse density used in this study was much greater $\left(10.43\right.$ pulses $\left./ \mathrm{m}^{2}\right)$ than is common $\left(\sim 1 \mathrm{pulse} / \mathrm{m}^{2}\right)$ in operational applications of the area-based approach, and as a result, the performance of the ALS may be somewhat exaggerated.

The studies of Bohlin et al. [8] and Järnstedt et al. [9] were both located in managed, single-layer, even-aged stands and therefore the extent to which their results are representative of more complex, multi-aged, multi-layered stands is uncertain. Evidently, there is a need to compare the capabilities of ALS and image-based point clouds in the area-based approach for forest attribute estimation across a range of forest types and stand conditions. St-Onge et al. [45] compared image-based and ALS CHMs and found that the ALS CHM had a larger standard deviation than the image-based CHM, but that the mean and maximum heights, and 95th and 99th percentiles of height differed by less than $1.69 \mathrm{~m}$ and were strongly correlated (with $r$ up to 0.95 for the 95th percentile). These results are notable considering that the image-based CHM in this case was built from the stereo-matching of digital images and not using the more advanced SGM approach to image matching and DSM generation. While the results of both Bohlin et al. [8] and Järnstedt et al. [9] indicate that the performance of ALS- and image-based predictive models of forest inventory attributes are somewhat similar (Table 4), neither study provides a detailed comparison of the similarities and differences between the various ALS metrics.

Since both ALS and image-based DSMs are capable of characterizing canopy height with similar levels of accuracy in more homogenous forest environments (i.e., single layer, even-aged stands) where it has been tested thus far, and since height is an important predictor of dominant height, basal 
area, and volume [14,57] it is not surprising that the predictions based on the image-based metrics in these studies are similar to those generated from the ALS metrics (Table 4). However, more detailed investigations of the similarities and differences between metrics generated from image-based DSMs or point clouds and ALS point clouds are required. In particular, comparisons of height distribution and canopy density metrics are relevant for applications that seek to quantify vertical forest structure [46], predict vertical foliage density profiles [58], or characterize the vertical distribution of LAI [54]. As stated earlier, the key difference between ALS and image-based point clouds are that ALS point clouds are capable of characterizing the vertical distribution of vegetation in the canopy, whereas image-based point clouds only characterize the outer canopy envelope (Figure 2). Furthermore, comparisons must be conducted in a broader range of stand complexities to determine if similar accuracies for ALS and image-based estimates of forest inventory attributes are achieved when stand conditions are more heterogeneous (i.e., multi-layered, uneven aged stands).

\subsection{Cost}

Interest in exploring alternatives to ALS data stems from a need to control costs. The cost-effective reduction of the inventory cycle (which is typically 10 to 20 years) is consistently demanded by forest managers in Canada and other jurisdictions, and represents a significant research need [59]. Without delving into specific pricing, which is in constant flux and highly situation-dependent, imagery is currently about one-half to one-third of the cost of ALS data. Thus, if ALS-equivalent area-based predictions can be made from imagery (something that has yet to be demonstrated for a range of forest types and stand structures), forest managers could potentially realize more frequent inventory cycles. Since it is envisioned that image acquisition will always play a role in forest inventory development and update, the ability to also estimate forest inventory attributes with robust area-based predictions from image-based point clouds - rather than the current practice of projecting attributes forward based on averaged growth or yield curves - would be an attractive option for forest managers. However, to reiterate, the use of image-based point clouds is predicated on the availability of high spatial resolution DEMs and therefore, an initial investment in ALS data is required before the potential cost savings afforded by image-based point clouds could be realized. Experience has indicated that the operational efficiencies associated with having the ALS-derived DEM, combined with improved attribute estimates made using the ALS point cloud metrics in an area-based approach, can largely offset the costs associated with acquiring and processing the ALS data (e.g., [14,60]).

\section{Summary and Conclusions}

ALS has emerged as a highly accurate technology, providing information that enhances forest inventories, improves efficiencies, reduces costs, increases competitiveness, and ultimately, improves decision making [5,21]. While ALS has been the primary source of vertical structural information for enhanced forest inventories, there has been growing interest in the use of image-based point clouds to provide three-dimensional information similar to that provided by ALS data. Currently, there is limited research into the use of image-based point clouds for this purpose. In this communication, we have summarized the key similarities and differences between these two data sources, with an aim to informing forest managers and highlighting key research questions. 
In comparing the two data sources we note that imagery has certain advantages over ALS in terms of acquisition that contribute to the lower cost of imagery relative to ALS. Moreover, imagery is a key data source for forest inventory, enabling the implementation of standard inventory practices, including stand delineation and visual interpretation of attributes such as species, which cannot (at this time) be estimated from ALS exclusively. As a result, any new forest inventory for a given area for which ALS will be acquired will also require some consideration of how attributes that are not readily generated from ALS will be acquired. Typically, imagery of some kind will be necessary; however, when updating an existing inventory, it is possible that new imagery would not be required. Reference to the actual information required is necessary to determine the need for, and type of imagery desired.

A main advantage of ALS data is the ability to generate a detailed DEM under the forest canopy, which, in addition to its utility for inventory, affords a broad range of operational and engineering applications, such as block and road layout, as well as information on the underlying hydrology and local radiation regimes [61]. In contrast, it is not possible to generate a DEM from an image-based point cloud if the ground is obscured by vegetation. Given that a detailed DEM is a necessary prerequisite for normalizing an image-based point cloud to aboveground heights, it is therefore likely that the use of image-based point clouds for forest inventory will be limited to those areas which already have a pre-existing high spatial resolution DEM (likely derived from ALS data).

The key difference between these two data sources is that ALS is capable of penetrating the canopy and providing information on sub-canopy structure, whereas image-based point clouds are limited to characterizing the upper canopy envelope. To date, there are only two studies that have compared the use of ALS and image-based point cloud/DSM metrics in the area-based approach to forest inventory attribute estimation. While the results of these studies indicate that image-based three-dimensional information can provide estimates of forest attributes such as height, basal area, and volume with accuracies that are similar to those achieved with ALS, the accuracy of the ALS estimates have always been greater. These studies have also been conducted in relatively simple forest stand conditions. There have been no rigorous assessments published in the literature that compare the relative accuracies of canopy heights from ALS and image-based point clouds over a range of forest types and terrain complexities. In addition, no studies have provided a detailed comparison of the metrics themselves, particularly height distribution and canopy density metrics, which we know will differ based on the ability of the ALS pulses to penetrate the canopy and provide information on sub-canopy structure. Furthermore, it is not yet understood what the more limited number of metrics afforded by an image-based point cloud will have on the estimation of forest attributes in more complex forest environments.

Mitigating the urgency of the debate over which data source to select for operational forest inventory activities is the need for an ALS-derived DEM as a prerequisite for the generation of an image-based normalized DSM and point cloud. In Canada and other jurisdictions, many resource managers who may be interested in using an image-based DSM do not currently have coverage with ALS data. Research activities focused on the potential and limits of using image-based DSMs and point clouds are ongoing. From a Canadian perspective, it is critical that comparative work between ALS- and image-based estimates of forest inventory attributes be undertaken in more complex forest environments. 
Given the current state of knowledge, it is not possible to conclude whether image-based point clouds are a viable source of three-dimensional information for enhanced forest inventories. More research is required on the topics raised herein before any definitive recommendation on the use of image-based point clouds can be made. As this is a very active topic of research in Canada and other jurisdictions, the results of additional studies are likely to emerge in the near future.

\section{Acknowledgments}

The authors acknowledge the support of the Canadian Wood Fibre Centre of the Canadian Forest Service, Natural Resources Canada. The contributions of Mikko Vastaranta to this manuscript were made possible by funding from the Academy of Finland (project "Towards Precision Forestry").

\section{Conflict of Interest}

The authors declare no conflict of interest.

\section{References}

1. Van Leeuwen, M.; Nieuwenhuis, M. Retreival of forest structural parameters using LiDAR remote sensing. Eur. J. For. Res. 2010, 129, 749-770.

2. Lim, K.; Treitz, P.; Wulder, M.A.; St-Onge, B.; Flood, M. LiDAR remote sensing of forest structure. Prog. Phys. Geogr. 2003, 27, 88-106.

3. Reutebuch, S.E.; Andersen, H.-E.; McGaughey, R.J. Light detection and ranging (LIDAR): An emerging tool for multiple resource inventory. J. For. 2005,103, 286-292.

4. Evans, D.L.; Roberts, S.D.; Parker, R.C. LiDAR-A new tool for forest measurements. For. Chron. 2006, 62, 211-219.

5. Wulder, M.A.; Bater, C.W.; Coops, N.C.; Hilker, T.; White, J.C. The role of LiDAR in sustainable forest management. For. Chron. 2008, 84, 807-826.

6. Hyyppä, J.; Hyyppä, H.; Leckie, D.; Gougeon, F.; Yu, X.; Maltamo, M. Review of methods of small-footprint airborne laser scanning for extracting forest inventory data in boreal forests. Int. J. Remote Sens. 2008, 29, 1339-1366.

7. Leberl, F.; Irschara, A.; Pock, T.; Meixner, P.; Gruber, M.; Scholz, S.; Wiechert, A. Point clouds: LiDAR versus three-dimensional vision. Photogramm. Eng. Remote Sens. 2010, 76, 1123-1134.

8. Bohlin, J.; Wallerman, J.; Fransson, J.E.S. Forest variable estimation using photogrammetric matching of digital aerial images in combination with a high-resolution DEM. Scand. J. For. Res. 2012, 27, 692-699.

9. Järnstedt, J.; Pekkarinen, A.; Tuominen, S.; Ginzler, C.; Holopainen, M.; Viitala, R. Forest variable estimation using a high-resolution digital surface model. ISPRS J. Photogramm. Remote Sens. 2012, 74, 78-84.

10. Næsset, E.; Gobakken, T.; Holmgren, J.; Hyyppä, H.; Hyyppä, J.; Maltamo, M.; Nilsson, M.; Olsson, H.; Persson, Å.; Söderman, U. Laser scanning of forest resources: The Nordic experience. Scand. J. For. Res. 2004, 19, 482-499. 
11. Stoker, J.M. Are we moving past the pixel? The third dimension in national landscape mapping. Photogramm. Eng. Remote Sens. 2013, 79, 133-134.

12. Wulder, M.A.; White, J.C.; Bater, C.W.; Coops, N.C.; Hopkinson, C.; Chen, G. Lidar plots-A new large-area data collection option: Context, concepts, and case study. Can. J. Remote Sens. 2012, 38, 600-618.

13. Hyyppä, J.; Inkinen, M. Detecting and estimating attributes for single trees using laser scanner. Photogramm. J. Finl. 1999, 16, 27-42.

14. Næsset, E. Predicting forest stand characteristics with airborne scanning laser using a practical two-stage procedure and field data. Remote Sens. Environ. 2002, 80, 88-99.

15. Næsset, E.; Bjerknes, K.-O. Estimating tree heights and number of stems in young forest stands using airborne laser scanner data. Remote Sens. Environ. 2001, 78, 328-340.

16. Lim, K.; Treitz, P.; Baldwin, K.; Morrison, I.; Green, J. Lidar remote sensing of biophysical properties of tolerant northern hardwood forests. Can. J. Remote Sens. 2003, 29, 658-678.

17. Holmgren, J. Prediction of tree height, basal area, and stem volume in forest stands using airborne laser scanning. Scand. J. For. Res. 2004, 19, 543-553.

18. Corona, P.; Fattorini, L. Area-based lidar-assisted estimation of forest standing volume. Can. J. For. Res. 2008, 38, 2911-2916.

19. Rooker Jensen, J.L.; Humes, K.S.; Conner, T.; Williams, C.J.; DeGroot, J. Estimation of biophysical characteristics for highly variable mixed-conifer stands using small-footprint LiDAR. Can. J. For. Res. 2006, 36, 1129-1138.

20. Hawbaker, T.J.; Gobakken, T.; Lesak, A.; Trømborg, E.; Contrucci, K.; Radeloff, V. Light detection and ranging-based measures of mixed hardwood forest structure. For. Sci. 2010, 56, 313-326.

21. Woods, M.; Pitt, D.; Penner, M.; Lim, K.; Nesbitt, D.; Etheridge, D.; Treitz, P. Operational implementation of a LiDAR inventory in boreal Ontario. For. Chron. 2011, 87, 512-528.

22. Lindberg, E.; Hollaus, M. Comparison of methods for estimation of stem volume, stem number, and basal area from airborne laser scanning data in a hemi-boreal forest. Remote Sens. 2012, 4, 1004-1023.

23. Nord-Larsen, T.; Schumacher, J. Estimation of forest resources from a country-wide laser scanning survey and national forest inventory data. Remote Sens. Environ. 2012, 119, 148-157.

24. Næsset, E. Airborne laser scanning as a method in operational forest inventory: Status of accuracy assessments accomplished in Scandinavia. Scand. J. For. Res. 2007, 22, 433-442.

25. Wehr, A.; Lohr, U. Airborne laser scanning-An introduction and overview. ISPRS J. Photogramm. Remote Sens. 1999, 54, 68-82.

26. Dubayah, R.O.; Drake, J.B. LiDAR remote sensing for forestry. J. For. 2000, 98, 44-46.

27. Reutebuch, S.E.; McGaughey, R.J.; Andersen, H.-E.; Carson, W.W. Accuracy of a high-resolution lidar terrain model under a conifer forest canopy. Can. J. Remote Sens. 2003, 29, 527-535.

28. Reutebuch, S.E.; McGaughey, R.J. LiDAR: An emerging tool for multiple resource measurement, planning, and monitoring. West. For. 2008, 53, 1-2.

29. Magnusson, M.; Fransson, J.E.S.; Holmgren, J. Effects on estimation accuracy of forest variables using different pulse density of laser data. For. Sci. 2007, 53, 619-626. 
30. Treitz, P.; Lim, K.; Woods, M.; Pitt, D.; Nesbitt, D.; Etheridge, D. LiDAR sampling density for forest resource inventories in Ontario, Canada. Remote Sens. 2012, 4, 830-848.

31. Jakubowski, M.K.; Guo, Q.; Kelly, M. Tradeoffs between lidar pulse density and forest measurement accuracy. Remote Sens. Environ. 2013, 130, 245-253.

32. Gatziolis, D.; Fried, J.S.; Monleon, V.S. Challenges to estimating tree height via LiDAR in closed-canopy forests: A parable from western Oregon. For. Sci. 2010, 56, 139-155.

33. Tinkham, W.T.; Smith, A.M.S.; Hoffman, C.; Hudak, A.T.; Falkowski, M.J.; Swanson, M.E.; Gessler, P.E. Investigating the influence of LiDAR ground surface errors on the utility of derived forest inventories. Can. J. For. Res. 2012, 42, 413-422.

34. Meng, X.; Currit, N.; Zhao, K. Ground filtering algorithms for airborne LiDAR data: A review of critical issues. Remote Sens. 2010, 2, 833-860.

35. McGaughey, R.J. FUSION/LDV: Software for LiDAR Data Analysis and Visualization. February 2013-FUSION Version 3.30. USDA Forest Service, Pacific Northwest Research Station, University of Washington, Seattle, WA, USA, 2013. Available online: http://www.forsys.cfr.washington.edu/fusion/FUSION_manual.pdf (accessed on 15 May 2013).

36. Lillesand, T.M.; Kiefer, R.W. Remote Sensing and Image Interpretation, 2nd ed.; John Wiley and Sons: New York, NY, USA, 1987.

37. Korpela, I. Individual tree measurements by means of digital aerial photogrammetry. Silva Fennica Monogr. 2004, 3, 93.

38. Gagnon, P.A.; Agnard, J.P.; Nolette, C. Evaluation of a soft-copy photogrammetry system for tree plot measurements. Can. J. For. Res. 1993, 23, 1781-1785.

39. Hall, R.J. The Roles of Aerial Photographs in Forestry Remote Sensing Image Analysis. In Remote Sensing of Forest Environments: Concepts and Case Studies; Wulder, M.A., Franklin, S.E., Eds.; Kluwer Academic Publishers: London, UK, 2003; pp. 47-77.

40. Zitová, B.; Flusser, J. Image registration methods: A survey. Image Vis. Comput. 2003, 21, 977-1000.

41. Baltsavias, E.; Gruen, A.; Eisenbeiss, H.; Zhang, L.; Waser, L.T. High-quality image matching and automated generation of three-dimensional tree models. Int. J. Remote Sens. 2008, 29, 1243-1259.

42. Haala, N.; Hastedt, H.; Wolf, K.; Ressl, C.; Baltrusch, S. Digital photogrammetric camera evaluation-Generation of digital elevation models. Photogramm Fernerkun. 2010, 2, 99-115.

43. Gehrke, S.; Morin, K.; Downey, M.; Boehrer, N.; Fuchs, T. Semi-Global Matching: An Alternative to LiDAR for DSM Generation? In Proceedings of the 2010 Canadian Geomtics Conference and Symposium of Commission I, ISPRS Convergence in Geomatics-Shaping Canada's Competitive Landscape, Calgary, Canada, 15-18 June 2010. Available online: http://www. isprs.org/proceedings/XXXVIII/part1/11/11_01_Paper_121.pdf (accessed on 21 January 2013).

44. Hirshmüller, H. Stereo processing by semi-global matching and mutual information. IEEE Trans. Pattern Anal. Mach. Intell. 2008, 30, 328-341.

45. St-Onge, B.; Vega, C.; Fournier, R.A.; Hu, Y. Mapping canopy height using a combination of digital stereo-photogrammetry and lidar. Int. J. Remote Sens. 2008, 29, 3343-3364. 
46. Zimble, D.A.; Evans, D.L.; Carlson, G.C.; Parker, R.C.; Grado, S.C.; Gerard, P.D. Characterizing vertical forest structure using small-footprint airborne LiDAR. Remote Sens. Environ. 2003, 87, 171-182.

47. Baltsavias, E. A comparison between photogrammetry and laser scanning. ISPRS J. Photogramm. Remote Sens. 1999, 54, 83-94.

48. Lim, K.; Hopkinson, C.; Treitz, P. Examining the effects of sampling point densities on laser canopy height and density metrics. For. Chron. 2008, 84, 876-885.

49. Hodgson, M.E.; Bresnahan, P. Accuracy of airborne lidar-derived elevation: Empirical assessment and error budget. Photogramm. Eng. Remote Sens. 2004, 70, 331-339.

50. Persson, A.; Holmgren, J.; Soderman, U. Detecting and measuring individual trees using an airborne laser scanner. Photogramm. Eng. Remote Sens. 2002, 68, 925-932.

51. Andersen, H.E.; Reutebuch, S.E.; McGaughey, R.J. A rigorous assessment of tree heigh measurements obtained using airborne lidar and conventional field methods. Can. J. Remote Sens. 2006, 32, 355-366.

52. Kaartinen, H.; Hyyppä, J.; Yu, X.; Vastaranta, M.; Hyyppä, H.; Kukko, A.; Holopainen, M.; Heipke, C.; Hirschmugl, M.; Morsdorf, F.; et al. An international comparison of individual tree detection and extraction using airborne laser scanning. Remote Sens. 2012, 4, 950-974.

53. Næsset, E. Determination of mean tree height of forest stands using airborne laser scanner data. ISPRS J. Photogramm. Remote Sens. 1997, 52, 49-56.

54. Magnussen, S.; Boudewyn, P. Derivations of stand heights from airborne laser scanner data with canopy-based quantile estimators. Can. J. For. Res. 1998, 28, 1016-1031.

55. Magnussen, S.; Eggermont, P.; LaRiccia, V. Recovering tree heights from airborne laser scanner data. For. Sci. 1999, 45, 407-422.

56. Næsset, E.; Økland, T. Estimating tree height and tree crown properties using airborne scanning laser in a boreal nature reserve. Remote Sens. Environ. 2002, 79, 105-115.

57. Maltamo, M.; Eerikäinen, K.; Packalén, P.; Hyyppä, J. Estimation of stem volume using laser scanning-based canopy height metrics. Forestry 2006, 79, 217-230.

58. Coops, N.C.; Hilker, T.; Wulder, M.A.; St-Onge, B.; Newnham, G.; Siggins, A.; Trofymow, J.A. Estimating canopy structure of douglas-fir forest stands from discrete-return LiDAR. Trees 2007, 21, 295-310.

59. Pitt, D.; Pineau, J. Forest inventory research at the Canadian Wood Fibre Centre: Notes from a research coordination workshop, 3-4 June 2009, Point Claire, QC. For. Chron. 2009, 85, 859-869.

60. Eid, T.; Gobakken, T.; Næsset, E. Comparing stand inventories for large areas based on photo-interpretation and laser scanning by means of cost-plus-loss analyses. Scand. J. For. Res. 2004, 19, 512-523.

61. White, B.; Ogilvie, J.; Campbell, D.M.H.; Hiltz, D.; Gauthier, B.; Chisholm, H.K.; Wen, H.K.; Murphy, P.N.C.; Arp, P.A. Use of a cartographic depth-to-water index to locate small streams and associated wet areas across landscapes. Can. Water Resour. J. 2012, 37, 333-347.

(C) 2013 by the authors; licensee MDPI, Basel, Switzerland. This article is an open access article distributed under the terms and conditions of the Creative Commons Attribution license (http://creativecommons.org/licenses/by/3.0/). 